Volume 15, No. 2, Juli 2018

\title{
EFEKTIVITAS SINGKONG MENTAH (Manihot esculenta) SEBAGAI RODENTISIDA NABATI TERHADAP PENGENDALIAN TIKUS MENCIT (Mus musculus)
}

\author{
Ayu Noer Fazriyawati, Hardiono, Rahmawati \\ Poltekkes Kemenkes Banjarmasin Jurusan Kesehatan Lingkungan \\ Jl. H. Mistar Cokrokusumo No.1A Banjarbaru Kalimantan Selatan 70714 \\ Email: anf0896@gmail.com
}

\begin{abstract}
Abstrack: The Effectiveness Of Raw Cassava As A Vegetable Rodenticide (Manihot esculenta) To Control The Mice(Mus musculus). Mice are rodents that cause economic losses and disease carriers for humans. Control is often done by using rodenticide containing toxic chemicals, but its use is not enviromentally responsible way. As an alternative to rodenticide then using vegetable rodenticide made from natural material, one of which cassava contain cyanide acid. This compound is dangerous, if consumed will be quickly absorbed by the digestive tract and into the bloodstream, can cause pain and even cause death. This study aimed to find out $L D_{50}$ raw cassava against white mice death. This type of research was an experiment with Post-test Only Control Group Design. The sample used were 50 male white mice of the Mus musculus species with the amount of rodenticide treatment of $40 \mathrm{gram}, 60 \mathrm{gram}, 80 \mathrm{gram}$ and $100 \mathrm{gram}$. The results obtained the highest mortality mortality of $60 \%$ at a dose of $100 \mathrm{gra}$ with a consumption rate of $62,48 \mathrm{gram}$. Calculation results $L D_{50}$ with probit analysis method obtained $L D_{50}$ value of 62,48 gram, so the conclusion is $61,60 \mathrm{~g}$ doses of cassava is capable of using the death of $50 \%$ mice.
\end{abstract}

Keywords : Mice; Raw cassava; Vegetable rodenticide

\begin{abstract}
Abstrak: Efektivitas Singkong Mentah (Manihot Esculenta) Sebagai Rodentisida Nabati Terhadap Pengendalian Tikus Mencit (Mus Musculus). Tikus adalah hewan pengerat yang menimbulkan kerugian ekonomi dan pembawa penyakit bagi manusia. Pengendalian yang sering dilakukan adalah dengan menggunakan rodentisida yang mengandung senyawa kimia beracun, namun tidak ramah lingkungan. Sebagai alternatif pengurangan rodentisida maka menggunakan rodentisida nabati yang terbuat dari bahan alami, salah satunya singkong yang mengandung asam sianida. Senyawa ini berbahaya, jika termakan akan cepat terserap oleh alat pencernaan dan masuk ke aliran darah, dapat menyebabkan sakit bahkan menimbulkan kematian. Penelitian ini bertujuan untuk mengetahui $\mathrm{LD}_{50}$ singkong mentah terhadap kematian mencit putih. Jenis penelitian adalah Eksperiment dengan desain Post-test Only Control Group Design. Sampel yang digunakan sebanyak 50 ekor mencit putih jantan spesies Mus musculus dengan jumlah perlakuan rodentisida sebesar 40 gram, 60 gram, 80 gram dan 100 gram. Hasil penelitian didapatkan kematian mencit tertinggi sebesar $60 \%$ pada dosis 100 gram dengan rerata konsumsi umpan sebesar 62,48 gram. Hasil perhitungan $\mathrm{LD}_{50}$ dengan metode analisis probit didapatkan nilai $\mathrm{LD}_{50}$ sebesar 61,60 gram, sehingga kesimpulannya adalah dosis 61,60 gram singkong sudah mampu menyebabkan kematian $50 \%$ mencit.
\end{abstract}

Kata kunci : Mencit; Singkong mentah; Rodentisida nabati

\section{PENDAHULUAN}

Tikus merupakan satwa liar yang sangat sering berhubungan dengan manusia. Kerugian yang ditimbulkan oleh tikus tersebut yaitu seperti merusak alat-alat rumah tangga bahkan dapat mengakibatkan kerugian ekonomi yang tinggi dalam sistem pertania [1].

Belum banyak diketahui dan disadari bahwa kelompok hewan ini juga membawa, menyebarkan dan menularkan berbagai penyakit kepada manusia, ternak dan hewan peliharaan. Penyakit bersumber rodensia yang disebabkan oleh berbagai agen penyakit seperti virus, rickettsia, bakteri, protozoa dan cacing dapat ditularkan kepada manusia secara langsung melalui fases, urin dan ludah atau gigitan rodensia dan pinjal secara tidak langsung. Beberapa penyakit yang ditularkan melalui tikus pernah dilaporkan secara klinis dan serologis pada 
manusia antara lain pes, murine typhus, leptospirosis, salmonelosis ${ }^{[2] .}$

Pengendalian tikus dikelompokkan menjadi beberapa metode antara lain pengendalian secara teknis, fisik mekanis, biologi dan kimia [3]. Pengendalian yang paling sering dilakukan adalah secara kimiawi, karena praktis dan hasilnya segera dapat terlihat tetapi apabila digunakan secara terus menerus dapat menimbulkan berbagai masalah baru [4]. Salah satu teknik yang sering dilakukan masyarakat adalah penggunaan rodentisida. Rodentisida digolongkan atas rodentisida fumigan dan umpan beracun. Umpan beracun ini dapat berupa racun akut dan racun kronis.

Rodentisida menunjukkan daya bunuh efektif serta memberikan hasil kematian tikus yang nyata meskipun penggunaannya tidak ramah lingkungan [3].

Sebagai alternatif pengurangan penggunaan rodentisida adalah dengan menggunakan rodentisida yang ramah lingkungan atau rodentisida nabati, terbuat dari bahan-bahan yang berasal dari tanaman atau tumbuhan.

Penggunaan rodentisida nabati selain dapat mengurangi pencemaran lingkungan, harga relatif lebih murah dibandingkan dengan rodentisida sintetik. Rodentisida nabati dapat dibuat secara sederhana berupa larutan hasil perasan, rendaman, eksrak, dan rebusan bagian tumbuhan. Keunggulan rodentisida nabati yaitu murah dan mudah dalam proses pembuatan, aman terhadap lingkungan, serta sulit menimbulkan resistensi pada tikus. Selain itu terdapat pula kelemahannya yaitu daya kerja relatif lambat, kurang praktis, serta tidak tahan disimpan [1]. Salah satu contoh rodentisida nabati yang akan diteliti yaitu dengan menggunakan tanaman singkong mentah.

Singkong mengandung racun linamarin dan loustralin yang termasuk golongan glikosida sianogenik. Linamarin terdapat pada semua bagian tanaman, terutama terakumulasi pada akar dan daun. Jika singkong mentah atau yang dimasak kurang sempurna dikonsumsi maka racun tersebut akan berubah menjadi senyawa kimia yang dinamakan hidogren sianida, yang dapat menimbulkan gangguan kesehatan ${ }^{[5]}$.
Dosis sianida (HCN) yang dapat menyebabkan kematian pada hewan yaitu sebanyak 0,5-3,5 mg HCN/kg berat badan [6]. Hasil uji pendahuluan kadar HCN pada singkong yang ditanam di daerah Liang Anggang diperoleh hasil bahwa kandungan HCN pada 1 kg singkong mentah sebanyak 2,214 ppm atau 2,214 $\mathrm{mg} \mathrm{HCN} / \mathrm{kg}$ singkong. Pemeriksaan tersebut dilakukan di laboratorium FMIPA Universitas Lambung Mangkurat Banjarbaru. Berdasarkan hal tersebut, peneliti tertarik untuk melakukan penelitian efektivitas singkong mentah sebagai rodentisida nabati dalam pengendalian tikus.

Tujuan penelitian adalah diketahuinya $\mathrm{LD}_{50}$ rodentisida nabati singkong mentah terhadap kematian mencit putih spesies Mus musculus. Penelitian bermanfaat sebagai tambahan pengetahuan dan informasi tentang singkong (Manihot esculenta) sebagai rodentisida nabati terhadap kematian tikus serta memperkaya pengetahuan ilmiah, khususnya pengendalian vektor dan binatang pengganggu.

\section{BAHAN DAN CARA PENELITIAN}

Jenis penelitian ini adalah Eksperimant, dengan rancangan Post-test Only Control Group Design. Penelitian dilaksanakan di ruangan yang sudah tidak digunakan lagi. Waktu penelitian dilaksanakan pada bulan Februari-Juni 2018. Hewan uji yang digunakan adalah mencit putih spesies Mus musculus dengan berat badan berkisar antara 18-21g. Mencit yang dipergunakan sebanyak 50 ekor mencit putih dengan pengamatan waktu kontak selama 7 hari setelah umpan dimasukan kedalam kurungan percobaan.

Sebelum melakukan penelitian, dilakukan uji pendahuluan dengan memeriksa kandungan HCN pada singkong mentah, sehingga dari hasil uji pendahuluan tersebut akan didapatkan variasi dosis umpan rodentisida nabati yaitu sebesar 40 gram, 60 gram, 80 gram dan 100 gram. Data yang diperoleh kemudian dianalisis dengan menggunakan analisis probit yaitu untuk mengetahui daya bunuh singkong mentah (Manihot esculenta) terhadap mencit putih spesies Mus musculus yang dinyatakan dengan LD 50 (Lethal Dosis 50\%). 


\section{HASIL PENELITIAN DAN PEMBAHASAN Jumlah Umpan Singkong yang Dikon- sumsi Mencit Putih}

Singkong yang disediakan untuk mencit tidak semua habis dimakan. Hal ini ditunjukkan pada akhir perlakuan masih tersisa singkong. Selisih antara berat singkong yang disediakan dengan singkong yang disediakan pada perlakuan dinyatakan sebagai dosis yang dimakan mencit. Ratarata dosis umpan yang dimakan mencit ditunjukkan pada Tabel 5.3 berikut:

Tabel 1. Dosis Umpan yang Dimakan Oleh Mencit Putih

\begin{tabular}{ccccc}
\hline $\begin{array}{c}\text { Mencit } \\
\text { ke }\end{array}$ & $\begin{array}{c}\text { Kelompok } \\
1\end{array}$ & $\begin{array}{c}\text { Kelompok } \\
2\end{array}$ & $\begin{array}{c}\text { Kelompok } \\
3\end{array}$ & $\begin{array}{c}\text { Kelompok } \\
\end{array}$ \\
& $(40 \mathrm{~g})$ & $(60 \mathrm{~g})$ & $(80 \mathrm{~g})$ & $(100 \mathrm{~g})$ \\
\hline 1 & 23,8 & 39,4 & 53,9 & 40 \\
2 & 26,9 & 39,8 & 58,1 & 40,2 \\
3 & 26,7 & 39,5 & 57,3 & 47,8 \\
4 & 26 & 39,4 & 59,4 & 54,4 \\
5 & 23,8 & 38,1 & 58,5 & 57,2 \\
6 & 24,2 & 46 & 61,7 & 57,9 \\
7 & 29,3 & 44,2 & 64,3 & 77,4 \\
8 & 32,9 & 48,6 & 60,8 & 79,5 \\
9 & 34 & 47 & 63,7 & 83,7 \\
10 & 29,8 & 43,7 & 64 & 86,7 \\
Rata-rata & 27,74 & 42,57 & 60,17 & 62,48 \\
\hline
\end{tabular}

Berat umpan singkong mentah ratarata berkurang dari berat awal umpan. Semakin besar umpan yang diberikan, maka mencit semakin banyak memakan umpan tersebut.

Dari data dosis umpan yang dikonsumsi mencit putih terlihat bahwa setiap perlakuan menunjukkan kenaikan konsumsi umpan, sedangkan jumlah pakan mencit dalam sehari berkisar antara 3,5$4,5 \mathrm{~g}$. Berat umpan yang dikonsumsi mencit putih rata-rata berkurang setengah dari berat awal umpan, hal ini dikarenakan singkong mentah memiliki tekstur yang mudah untuk dikunyah dan memiliki aroma yang menarik, sehingga merangsang mencit untuk memakan singkong mentah tersebut [7].

\section{Perubahan Berat Badan Mencit setelah Perlakuan}

Berat badan mencit putih setelah mendapat perlakuan yakni memakan umpan yang disediakan dalam waktu seminggu menunjukkan perubahan. Perubahan berat badan mencit didapat dari berat mencit setelah perlakuan dikurangi berat mencit awal [8], hasilnya ditunjukkan pada Tabel 2.

Tabel 2. Berat Badan Mencit Putih Setelah Perlakuan

\begin{tabular}{cccc}
\hline Dosis yang dimakan & \multicolumn{2}{c}{ Rerata bobot tubuh (g) } & Perubahan (g) \\
(g) & Awal & Akhir & \\
\hline 0 (kontrol) & 20,17 & 24,39 & 4,22 \\
27,74 & 20,11 & 12,4 & $-7,71$ \\
42,57 & 19,76 & 12,77 & $-6,99$ \\
60,17 & 19,77 & 12,1 & $-7,67$ \\
62,48 & 20,15 & 11,97 & $-8,18$ \\
\hline
\end{tabular}

Berat badan mencit kelompok kontrol sesudah perlakuan mengalami kenaikan, sedangkan pada kelompok perlakuan semua mencit mengalami penurunan berat badan.
Rata-rata penuruanan berat badan berkisar antara 6,99g - 8,18g.

Berdasarkan data hasil penimbangan berat badan mencit sebelum dan sesudah 
perlakuan, ada perbedaan penurunan berat badan yang signifikan, hal ini disebabkan oleh kandungan sianida pada singkong mentah yang mampu mengganggu fungsi organ dalam seperti sistem pencernaan dalam tubuh. Apabila didalam tubuh terdapat zat toksik yang sangat tinggi, kemungkinan akan menyebabkan kerusakan sel yang tinggi sehingga banyak sel yang mati dan menyebabkan terganggunya proses metabolisme dalam tubuh, sehingga dapat menggangu fungsi normal organ yang akhirnya menghambat pertumbuhan dan menurunkan bobot tubuh [7].

Tidak menutup kemungkinan bahwa penurunan berat badan mencit putih diduga karena tidak ada variasi jenis umpan sehingga mencit putih menjadi bosan terhadap makanan yang diberikan dan akhirnya mengurangi nafsu makan sehingga dapat menurunkan berat badan mencit bahkan menyebabkan kematian terhadap mencit.

\section{Pengaruh Rodentisida Nabati terhadap Kematian Mencit Putih}

Jumlah kematian mencit putih bervariasi sesuai dengan dosis singkong yang dimakan seperti ditunjukkan pada Tabel 3. sebagai berikut:

Tabel 3. Distribusi Jumlah Kematian Mencit Berdasarkan Dosis Umpan Yang Dimakan

\begin{tabular}{ccc}
\hline $\begin{array}{c}\text { Dosis umpan yang } \\
\text { dimakan (g) }\end{array}$ & $\begin{array}{c}\text { Kematian mencit } \\
\text { Juml. yang mati } \\
\text { (ekor) }\end{array}$ & $\begin{array}{c}\text { Mortalitas } \\
(\%)\end{array}$ \\
\hline Kontrol & 0 & 0 \\
27,74 & 3 & 30 \\
42,57 & 4 & 40 \\
60,17 & 4 & 40 \\
62,48 & 6 & 60 \\
\hline
\end{tabular}

Data jumlah kematian mencit untuk masing-masing dosis singkong yang dimakan menunjukkan semakin tinggi dosis semakin besar tingkat kematian mencit, kematian tertinggi ada pada dosis umpan 62,48 g yakni sebesar $60 \%$. Hasil penelitian ini menunjukkan daya toksisitas singkong terhadap kematian mencit lebih rendah jika dibandingkan dengan daya toksisitas gadung.

Hasil penelitan Posmaningsih 2014 tentang penggunaan umbi gadung sebagai rodentisida nabati, menyebutkan bahwa dengan umpan $30 \mathrm{~g}$ gadung dapat membunuh tikus putih jenis Rattus norvegicus dengan rerata konsumsi gadung 6,89 gr sudah mampu membunuh tikus melebihi $L D_{50}$, sedangkan penelitian Dinar 2011 tentang penggunaan umbi gadung kadar $25 \%$ dengan paraffin, caramel, penyedap rasa dan beras mampu membunuh sampai 70\% tikus sawah. Dari hasil tersebut diketahui bahwa gadung daya bunuhnya lebih toksis dari pada singkong. Berdasarkan hasil penelitian, menunjukkan gadung mengandung dioskrin yaitu sejenis alkaloid yang larut dalam air dan dapat menyebabkan muntah darah, sukar bernafas dan kematian [3]. Selain itu gadung memiliki senyawa antimakan yang bersifat menghambat selera makan tikus [9].

Umpan singkong menyebabkan kematian hewan uji lebih rendah dibandingkan dengan umpan gadung, hal ini dikarenakan kandungan sianida pada umpan singkong dosisnya kecil yaitu sebanyak 2,214 ppm atau 2,214 $\mathrm{mg} \mathrm{HCN} / \mathrm{kg}$ singkong. Dari umpan singkong yang dimakan mencit diperkirakan kandungan sianida berkisar antara 0,70-1,59 mg HCN/kg singkong. Dosis sianida (HCN) yang dapat menyebabkan kematian pada hewan yaitu sebanyak 0,5 3,5 mg HCN/kg berat badan [6]. Selain itu jenis singkong yang berbeda juga memiliki kandungan sianida yang berbeda pula. Kandungan sianida dalam singkong sangat bervariasi, rata-rata dalam singkong manis kadar sianida kurang dari $50 \mathrm{mg} / \mathrm{kg}$ umbi, sedangkan pada jenis singkong pahit kadar sianida diatas $50 \mathrm{mg} / \mathrm{kg}$ umbi [6]. Penggunaan singkong manis menunjukkan kandungan sianida dalam singkong sedikit, sehingga 
mencit yang memakan umpan tersebut lambat menunjukkan reaksi keracunan oleh umpan tersebut [10].

Kematian mencit disebabkan oleh beberapa kemungkinan, yang pertama bisa disebabkan oleh kondisi lingkungan seperti suhu dan kelembaban yang mempengaruhi pertumbuhan, konsumsi umpan dan mortalitas, yang kedua diduga karena mencit putih bosan terhadap makanan yang diberikan dan akhirnya mengurangi nafsu makan, sehingga mencit tidak memakan habis umpan tersebut sampai penelitian berakhir, dan yang ketiga, tidak menutup kemungkinan disebabkan oleh umpan yang dimakan mencit dengan dosis tertinggi yakni 62,48g, menimbulkan efek toksisitas terhadap mencit yang mengakibatkan kematian.

Kematian mencit putih sebagai target rodentisida berdasarkan cara kerjanya dibagi menjadi dua golangan yaitu racun akut dan racun kronis [11]. Racun akut atau rodentisida akut menyebabkan kematian tikus dalam 24 jam atau kurang setelah pemberian pada dosis yang mematikan [11]. Kurun waktu tersebut berhubungan dengan tingkat dosis yang diberikan, akibat dari racun tersebut dapat dilihat nyata dengan waktu yang sangat cepat ketika diberikan rodentisida dalam jumlah besar. Racun akut bekerja lebih cepat dalam membunuh tikus dengan cara merusak sistem saraf dan melumpuhkannya. Salah satu racun akut yang sering digunakan adalah rodentisida yang berbahan aktif seng fosfida [11]. Sedangkan racun kronis/rodentisida kronis merupakan racun yang bekerja secara lambat. Rodentisida kronis mengandung senyawa yang dapat menghambat pembentukan protrombin dan merusak pembuluh darah [11].

Rodentisida kronis lebih sering digunakan dibandingkan dengan racun akut dalam pengendalian tikus karena dapat mengurangi sifat curiga dari tikus. Bahan aktif dari rodentisida kronis bekerja dalam tubuh tikus dengan lambat sehingga tikus tidak langsung mati di tempat setelah mengonsumsi racun [11]. Proses kematian yang menghabiskan waktu seminggu didasarkan bahwa tikus merupakan hewan yang pintar. Apabila kematian tikus berdekatan dengan rodentisida, maka tikus lainnya mampu mengkaitkan proses kematian temannya dengan umpan yang berada didekatnya. Selain itu tikus juga mempunyai perilaku neophobia atau curiga terhadap sesuatu makanan yang baru. Tikus hanya mencicipi sedikit makanan baru tersebut, apabila ada hal yang mencurigakan seperti membuat sakit, maka tikus segera memberi tanda bahaya berupa sinyal kimiawi bahwa umpan tersebut tidak boleh dimakan, sehingga tikus lainnya tidak akan memakan umpan tersebut hal inilah yang biasa disebut "jera umpan". Umpan singkong mentah sebagai rodentisida nabati adalah termasuk racun yang bekerja secara lambat (racun kronis), hanya saja berasal dari tumbuhan. Umpan tersebut bekerja lambat dalam mempengaruhi kematian mencit dan diperlukan waktu yang lama agar efek toksik atau racun dari umpan yang termakan oleh mencit dapat menyebar ke pembuluh darah dan menyebabkan kematian, namun penggunaannya ramah lingkungan [12].

Berdasarkan data kematian mencit yang diperoleh dari setiap perlakuan sampai hari ke 7 , ditentukan $\mathrm{LD}_{50}$ dengan menggunakan analisis probit. Hasil analisis diperoleh $\mathrm{LD}_{50}$ sebesar $61,60 \mathrm{~g}$ dan $\mathrm{LD}_{99}$ sebesar 205,70g singkong mentah. Berdasarkan hasil analisis ini dapat disimpulkan dengan dosis $61,60 \mathrm{~g}$ singkong mentah sudah mampu menyebabkan kematian mencit putih $50 \%$ dan dengan dosis sebesar 205,70g singkong mentah dapat mematikan mencit putih sebagai hewan uji 99\%. Sedangkan hasil penelitian Posmaningsih 2014 menunjukkan bahwa $\mathrm{LD}_{50}$ umpan gadung sebesar 6,89g sudah dapat mematikan tikus Rattus norvegicus $50 \%$ dan $\mathrm{LD}_{99}$ umpan gadung sebesar $52,76 \mathrm{~g}$ dapat mematikan tikus Rattus norvegicus $99 \%$.

\section{KESIMPULAN DAN SARAN}

Berdasarkan hasil penelitian dapat disimpulkan dengan menggunakan metode analisis probit didapatkan nilai $\mathrm{LD}_{50}$ sebesar $61,60 \mathrm{~g}$, yang artinya dengan dosis $61,60 \mathrm{~g}$ singkong sudah mampu menyebabkan kematian 50\% mencit, dan nilai $\mathrm{LD}_{99}$ sebesar 205,70g singkong mampu mematikan 99\% mencit. 
Saran yang dapat diberikan berdasarkan hasil yang telah didapat yaitu perlu dilakukan penelitian lebih lanjut dengan membuat ekstrak dari jenis singkong pahit dan dipadukan dengan bahan tambahan penarik tikus dan perlu menambah beberapa mencit dalam masingmasing kandang percobaan sehingga kematian mencit per kandang dapat bervariasi.

\section{KEPUSTAKAAN}

1. Pengujian Umbi Gadung (Dioscorea hispida Dennst.) sebagai Rodentisida Botanis Siap Pakai dalam Pengendalian Tikus Rumah (Rattus rattus diardii Linn.) dan Tikus Sawah (Rattus argentiventer Rob. \& Klo.). Murjani, Dwi Dinar. Bogor : Institut Pertanian Bogor, 2011.

2. Departeman Kesehatan RI Direktorat Jendral. Pedoman Pengendalian Tikus. Jakarta : Departeman Kesehatan, 2008.

3. Efektivitas Pemanfaatan Umbi Gadung Dioscorea hispida Dennust) pada Umpan Sebagai Rodentisida Nabati dalam Pengendalian Tikus. Posmaningsih, D.A.A, Purna, I Nyoman and Sali, I Wayan. 1, Denpasar: Poltekkes Denpasar, 2014, Vol. 11, pp. 79-85.

4. Pengendalian Tikus pada Tanaman Padi Melalui Pendekatan Ekologi. Baco, Djafar. 1, Makassar: Balai Pengkajian Teknologi Pertanian Sulawesi Selatan, 2011, Vol. 4, pp. 47-62.

5. Substitusi Tepung Kulit Singkong (Manihot Utillisima) dalam Pembuatan Mie dengan Penambahan Ekstrak Kelopak Bunga Rosella Kering (Hibiscus Sabdariffa Linn.) sebagai Pewarna Alami. Yuliani, Tri Tuti. Surakarta : Universitas Muhammadiyah Surakarta, 2014.

6. Kadar Sianida Tepung Ubi Kayu (Manihot esculenta Crantz) Melalui Perendaman Ubi Kayu dengan NaHCO3.
Siboro, Riwanto. Bengkulu : Universitas Bengkulu, 2016.

7. Kematian Mencit Putih Jantan (Mus musculus) yang Diberi Berbagai Jennis Umpan Mengandung Larutan Umbi Gadung (Dioscorea hispida) di Laboratorium. Irawan, Arnisa. Banjarbaru: Universitas Lambung Mangkurat, 2016.

8. Uji Efikasi Rodentisida Nabati Daun Ruku-ruku (Ocimum sanctum L.) terhadap Mortalitas Tikus Sawah (Rattus argentiventer Robb \& Kloss) di Laboratorium. Sinaga, Christine N.L, Tobing, Maryani Cyccu and Pinem, Mukhtar Iskandar. 2, Medan: Jurnal Agroekoteknologi FP USU, 2017, Vol. 5, pp. 434-443. ISSN.

9. Aktif Anti Makan dari Umbi Gadung (Dioscorea hispida Dennst.). Santi, Sri Rahayu. 1, Bukit Jimbaran : Universitas Udayana, 2010, Jurnal Kimia, Vol. 4, pp. 71-78. ISSN.

10. Uji Toksisitas Akut Ekstrak Etanol Daun Kayu Hitam (Diospyros celebica B.) Terhadap Mencit (Mus musculus). Syam, Aswin Khaliq. Makasar: Universitas Islam Negeri Alauddin, 2016.

11. Tingkat Kejeraan Tiga Spesies Tikus Hama Terhadap Rodentisida dan Umpan Serta Faktor Penyebabnya. Putri, Minkhaya Silviana. Bogor: Institut Pertanian Bogor, 2012.

12. Natawigena, Wahyu Daradjat. Dr. Ir. H. Wahyu Daradjat Natawigena, M.Si., Ciptakan Racun Tikus yang Efektif, Inovatif dan Aman Bagi Manusia. www.undap.ac.id. [Online] 06 15, 2017. [Cited: $07 \quad 11, \quad 2018$. http://www.unpad.ac.id/profol/dr-irh-wahyu-darajat-natawigena-m-siciptakan-racun-tikus-yang-efektifinovatif-dan-aman-bagi-manusia/. 